\title{
Zinc status of apple orchards across apple growing regions of Balochistan
}

\author{
Hidayatullah ${ }^{1 *}$, Gul Muhammad Panezai ${ }^{2}$, Rehmatullah Kethran ${ }^{2}$, Syed \\ Abdul Hadi Agha ${ }^{2}$, Nazeer Ahmed Alizai ${ }^{2}$ and Zainullah Khan ${ }^{3}$ \\ 1. Directorate of Agriculture Research Soil and Water Testing ARI Sariab Quetta-Pakistan \\ 2. Directorate of Agriculture Research (Fruits) ARI Sariab Quetta-Pakistan \\ 3. Directorate of Agriculture Research Grapes Pishin-Pakistan \\ *Corresponding author's email: kaintkk@gmail.com \\ Citation \\ Hidayatullah, Gul Muhammad Panezai, Rehmatullah Kethran, Syed Abdul Hadi Agha, Nazir Ahmed Alizai and \\ Zainullah Khan. Zinc status of apple orchards across apple growing regions of Balochistan. Pure and Applied \\ Biology. Vol. 8, Issue 1, pp920-930. http://dx.doi.org/10.19045/bspab.2019.80034
}

\begin{tabular}{llll}
\hline \hline Received: 06/12/2018 & Revised: 04/03/2019 & Accepted: 08/03/2019 & Online First: 25/03/2019 \\
\hline
\end{tabular}

\section{Abstract}

All plant essential nutrients except Molybdenum are not easily available in alkaline calcareous soils. Among them, the deficiency of micronutrients particularly Zinc and iron is widespread in crops and fruit orchards. For this purpose, a survey study was carried out across five districts of Balochistan viz Kalat, Killa Abdullah, Pishin, Quetta and Ziarat during 2016 aiming to determine both soil and leaf Zn status of apple orchards. The 150 soil and leaf samples were collected and statistically divided them as 30 samples of each district in 3 groups of 10 samples and analysed through one way analysis of variance. The results showed that soil $\mathrm{pH}$ of apple orchards was in alkaline range and EC was almost normal with statistically at par differences. While, the AB-DTPA extractable $\mathrm{Zn}$ in soil of various apple orchards across five districts revealed that 5, 23 and 2 orchards in Kalat, 3, 24 and 3 in Killa Abdullah, 1515 and 0.0 in Pishin and Ziarat while 20,10 and 0.0 in Quetta expressed low, marginal and adequate Zn concentration. The leaf tissue analysis for $\mathrm{Zn}$ status indicated that $23.3 \%$ apple orchards in Kalat, $6.7 \%$ in Killa Abdullah, 33.3\% in Pishin, 73.3\% in Quetta and 56.7\% in district Ziarat were found $\mathrm{Zn}$ deficient. Consequently, this study suggest that Zinc supplementation to soil of these orchards are needed while the addition of compost under such alkaline soil also necessary and is considered as one of the best management practices for apple orchards.

Keywords: Apple orchards; Leaf Zn concentration; Locations; Soil Zn concentration

\section{Introduction}

In agriculture, the zinc ( $\mathrm{Zn})$ has been recognized significantly one of the important mineral elements. The role of $\mathrm{Zn}$ as plant essential element and development of its essentiality was realized slowly [1]. The historical background of $\mathrm{Zn}$ indicate that during 1869 the student of Louis Pasteur viz Raulin first time described $\mathrm{Zn}$ requirement as nutrient for the prosper of fungi (Aspergillus niger) causing diseases in many agricultural crops like black mold disease of grapes, onion and peanuts. When $\mathrm{Zn}$ was confirmed as an essential element for growth of plants, now globally many areas have been identified deficient in $\mathrm{Zn}$ level and have adverse impact on growth performance and yield of crops, vegetables and fruits orchards. It has been reported that $\mathrm{Zn}$ status is found low in sandy and peat soils [2]. In calcareous soil, the deficiency of micronutrients particularly $\mathrm{Zn}$ is prevalent among all agriculturally important crops since the unavailability of $\mathrm{Zn}$ in such soil is 
due to its adsorption on clay and calcite, low $\mathrm{Zn}$ in the parent material, alkaline nature (high $\mathrm{pH}$ ), high calcium carbonate contents, high or low soil organic matter. While $\mathrm{Zn}$ deficiency in calcareous soil is also due to the dominancy of sodium $(\mathrm{Na})$, calcium $(\mathrm{Ca})$, magnesium $(\mathrm{Mg}), \mathrm{HCO}_{3}$ and high phosphorus level in soil [3, 4].

In Pakistan including the province of Balochistan, the reasons of low soil $\mathrm{Zn}$ status in orchards is linked to calcareous and alkaline nature of soil with low organic matter and in some cases the light soil texture is also responsible for $\mathrm{Zn}$ deficiency. While, the high contents of calcite make $\mathrm{Zn}$ unavailable by making calcium zincate which is insoluble [5]. In an approximation, the out of total area of the world $30-40 \%$ area is deficient in $\mathrm{Zn}[6,7]$ as in case of Pakistan, due to unavailability of nutrients under calcareous soil the average yield of apple orchard is $3.9 \mathrm{t} \mathrm{ha}^{-1}$ [8] which is quite low when compared to other neighboring countries. According to Lindsay [9] that a unit increases in soil $\mathrm{pH}$ correspondingly reduce the availability of $\mathrm{Zn} 100$ times. The scientific literature has manifested that most of fruit trees are vulnerable to Zn deficiency and among deciduous fruit trees, apple are highly susceptible to $\mathrm{Zn}$ deficiency $[10,11]$. Each nutrient plays a specific function in bio-physico-chemical process of all living things. In case of $\mathrm{Zn}$, its presence in sufficiency range is crucial because $\mathrm{Zn}$ is essential nutrient required for the prosper growth performance of plants as it play role in bursting of fruit buds, fertilization and reproduction and also equally important for sound health of human beings and animals. While, in some regions of the world soil and water contamination with $\mathrm{Zn}$ which reach to us through food chain [12-14]. Zinc main function is catalytic in nature for different enzymes [15]. These enzymes are involved in different biochemical processes like carbohydrate metabolism, protein synthesis, integrity of cell membranes, pollen development and auxin production. Other function of $\mathrm{Zn}$ in plants involved metabolism of nitrogen and its deficiency results in low protein production with stunted plant growth $[\mathbf{1 5}, \mathbf{1 6}]$.

Spatial variability in soil $\mathrm{Zn}$ status of Agriculture land has been noticed and has found to be ranged from 10 to $300 \mathrm{mg} \mathrm{kg}^{-1}$ $[17,18]$. While, in scientific reports the average soil $\mathrm{Zn}$ was noted about $50-55 \mathrm{mg}$ $\mathrm{kg}^{-1}$ [19]. Whereas, the world's soil average $\mathrm{Zn}$ contents was indicated as $64 \mathrm{mg} \mathrm{kg}^{-1}$ [20, 21]. The $\mathrm{Zn}$ deficiency has also been expressed in early growing seasons where temperature is low as well as in cool and wet soils that later on disappear when summer comes. The reason of low soil $\mathrm{Zn}$ is due to slow decomposition of organic matter by soil microbes during cool season that works as a slow release of $\mathrm{Zn}$ for crop. Inversely, rise in soil temperature lead to enhance $\mathrm{Zn}$ availability by increasing diffusion rate and accelerate organic matter mineralization rate [3]. In light of the importance of $\mathrm{Zn}$ in apple fruit production and its unavailability in calcareous and alkaline soil, this study was initiated to determine the soil and leaf $\mathrm{Zn}$ status of apple orchards in five districts of Balochistan, Pakistan.

\section{Materials and methods}

A field study was conducted during 2016 to evaluate the zinc status of apple orchards belonging to five districts of Baluchistan viz. Kalat, Killa Abdullah, Pishin, Quetta and Ziarat. The study consisted of two components, the first one involved the assessment of soil physico-chemical properties such as $\mathrm{pH}$, electrical conductivity (EC), ammonium bicarbonatediethylenetriaminepentaacetic acid (ABDTPA) extractable $\mathrm{Zn}$. while the second component comprised of leaf tissue analysis for determination of $\mathrm{Zn}$ in fruit bearing apple orchards. 
Thirty fruit bearing apple orchards of same age and variety (red delicious) were selected from different locations in Kalat, Killa Abdullah, Pishin, Quetta and Ziarat district of Baluchistan. Five trees were randomly selected from each orchard and composited for one sample. This way a total of 150 each soil and plant samples were collected.

\section{Soil and leaf sampling and processing}

Fifteen to twenty recently matured leaves were collected from the mid-portion of branch, covering the tree periphery and composited to one [22]. Soil samples from same trees were collected at the depth of 0 $30 \mathrm{~cm}$. In order to have a representative soil sample from each tree, four to six cores were dug underneath the tree canopy and composited to one. All the soil and leaf samples were properly labeled and delivered to the Soil and Water Testing Laboratory of Agriculture Research Institute (ARI), Quetta. The soil samples were air dried, ground and sieved through $2 \mathrm{~mm}$ mesh. Whereas, the leaf samples were decontaminated and washed [23], oven dried at $65^{\circ} \mathrm{C}$ [24], ground to 20 mesh and stored in plastic bags for target analysis.

\section{Soil and leaf analysis}

The soil was analyzed for some physicochemical properties by standard methods. Soil electrical conductivity (EC) and $\mathrm{pH}$ were determined in 1:2 soil water extract using EC meter and $\mathrm{pH}$ meter according to the method described by McKeague [25] and McLean [26]. While, AB-DTPA extraction solution was used for extracting soil $\mathrm{Zn} \mathrm{[27].} \mathrm{In} \mathrm{the} \mathrm{clear} \mathrm{filtrate} \mathrm{of} \mathrm{AB}$ DTPA soil extract, Zn was determined on Atomic Absorption Spectrophotometer at $880 \mathrm{~nm}$ wavelength.

From the prepared leaf samples, $0.5 \mathrm{~g}$ was weighed and wet digested using hot sulfuric acid with repeated additions of $30 \%$ hydrogen peroxide $\left(\mathrm{H}_{2} \mathrm{O}_{2}\right)$ until the digestion was completed, then this digest was used for the determination of zinc [28].

\section{Statistical analysis}

The collected data were subjected to oneway analysis of variance and also used descriptive statistics for determination of minimum, maximum and mean values and percentage. All statistical analysis was computed on Statistix 8.1 software (MathSoft Inc., Cambridge, MA, USA).

\section{Results and discussion}

In Balochistan province, apple fruit production occupies major position among deciduous fruits and is the main source of income of people in uplands of Balochistan. The main apple growing districts of Balochistan are Kalat, Killah Abdullah, Killa Saifullah, Mastung, Pishin, Quetta, and Ziarat. The contribution of Balochistan in deciduous fruits is higher as compared to other provinces of Pakistan and now Balochistan is called the "fruit basket" of Pakistan. However, both yield and quality of apple has declined to great extent which might be due to changes in environment, water scarcity and lack of adoption of best management practices. Soils in Pakistan including Balochistan is calcareous and alkaline in nature where nutrients availability to plants is one of the main constraints in agriculture production along with apple orchards enterprises. The micronutrient particularly zincs and iron deficiencies are widespread in all apple growing districts which have now affected growth and yield of apple substantially. So, for the assessment of zinc status of apple orchards, soil and leaf samples from apple orchards in 30 locations of each district were collected and analysed. There was great variability in the AB-DTPA extractable soil $\mathrm{Zn}$ concentration and leaf tissues $\mathrm{Zn}$ level of apple orchards. The soil analysis for $\mathrm{pH}$, $\mathrm{EC}_{\mathrm{e}}\left(\mathrm{dSm}^{-1}\right)$ and AB-DTPA extractable $\mathrm{Zn}$ concentration of five districts as given in (Table 1) revealed that soil $\mathrm{pH}$ in Kalat district was ranged from 8.02 to 8.33 , Killah Abdullah from 7.96 to 8.30, Pishin from 
8.10 to 8.39 , Quetta from 7.81 to 8.47 and Ziarat from 7.50 to 8.42 respectively. While, $\mathrm{EC}_{\mathrm{e}}$ was ranged from 1.63 to $4.48 \mathrm{dSm}^{-1}$ in Kalat, 2.55 to $4.80 \mathrm{dSm}^{-1}$ in Killa Abdullah, 1.66 to $4.91 \mathrm{dSm}^{-1}$ in Pishin, 0.51 to 3.31 $\mathrm{dSm}^{-1}$ in Quetta and 0.61 to $4.30 \mathrm{dSm}^{-1}$ in Ziarat. In case of AB-DTPA extractable soil $\mathrm{Zn}$, the overall $\mathrm{Zn}$ concentration in apple orchard soils of Kalat district was ranged from 46.5 to $132.5 \mathrm{mg} \mathrm{kg}^{-1}$, Killah Abdullah from 48.5 to $133.8 \mathrm{mg} \mathrm{kg}^{-1}$, Pishin from 29.4 to $98.3 \mathrm{mg} \mathrm{kg}^{-1}$, Quetta from 24.4 to 97.6 $\mathrm{mg} \mathrm{kg}^{-1}$ and Ziarat was from 25.5 to 116.0 $\mathrm{mg} \mathrm{\textrm {kg } ^ { - 1 }}$ respectively. Similarly, the leaf tissue $\mathrm{Zn}$ concentration of apple orchards in five districts are given in (Table 2) revealed that the overall mean of $\mathrm{Zn}$ concentration of 30 apple orchards in district Kalat was ranged from 14.6 to $85.1 \mathrm{mg} \mathrm{kg}^{-1}$, Killa Abdullah from 17.6 to $112.2 \mathrm{mg} \mathrm{kg}^{-1}$, Pishin from 11.7 to $120.1 \mathrm{mg} \mathrm{kg}^{-1}$, Quetta from 5.6 to $39.3 \mathrm{mg} \mathrm{kg}^{-1}$ and Ziarat from 5.0 to 55.2 $\mathrm{mg} \mathrm{kg}^{-1}$ respectively.

As 30 orchards were grouped into three groups of 10 orchards (locations) in each district and one-way analysis of variance was performed separately on each studied parameter. The result regarding soil $\mathrm{pH}, \mathrm{EC}_{\mathrm{e}}$ and AB-DTPA extractable $\mathrm{Zn}$ as given in (Table 1) showed that statistically $\mathrm{pH}$ values were at par in all ten locations of district Kalat, Killa Abdullah, Pishin, Quetta and Ziarat. The higher but statistically at par $\mathrm{pH}$ value of 8.26 was recorded in location 2, 9 and 10 with minimum $\mathrm{pH}$ of 8.14 in location 5 at Kalat while in Killa Abdullah the higher $\mathrm{pH}$ (8.17) was noted in location 3 and minimum $\mathrm{pH}$ value of 8.07 was observed in location 8. Similarly, in district Pishin the higher $\mathrm{pH}$ (8.35) was found in location 6 and lower $\mathrm{pH}$ was 8.17 . Whereas, the greater soil $\mathrm{pH}$ of 8.40 was recorded in location 7 with minimum $\mathrm{pH}$ (8.12) in location 3. The soil chemical reaction or $\mathrm{pH}$ in apple orchards at Ziarat indicated maximum $\mathrm{pH}$ (8.26) in location 7and minimum $\mathrm{pH}$ (7.83) in location 8. Soil $\mathrm{pH}$ plays an important role in the availability of nutrients. The soil $\mathrm{pH}$ values in all locations of five districts demonstrated that the soil is alkaline and in such condition the availability of nutrients is one of the constraints for better apple fruit production. While, the electrical conductivity of soil showed statistically at par differences in all locations and in each district that indicate that soil is non-saline with few exceptional cases in district Kalat and Killa Abdullah while the rest of districts manifest EC level in lower range (Table 1). However, AB-DTPA extractable soil Zinc concentration depicted different scenario of all five districts which were statistically highly significant $(\mathrm{p}<0.05)$. The apple orchards' soil Zn concentration at Kalat expressed higher but non-significant level of 112.7 and $112.2 \mathrm{mg} \mathrm{kg}^{-1}$ in location 1 and 2 followed by $104.7 \mathrm{mg} \mathrm{kg}^{-1}$ in location 3 but lower $\mathrm{Zn}$ concentration (58.5 $\mathrm{mg} \mathrm{kg}^{-1}$ ) was noted in location 6. Likewise, in district Killa Abdullah, location 5 indicated maximum available $\mathrm{Zn}$ concentration (110.5 $\mathrm{mg} \mathrm{kg}-1$ ) and location 6 reflected minimum $\mathrm{Zn}$ concentrations $\left(57.4 \mathrm{mg} \mathrm{kg}^{-1}\right)$ while in case of district Pishin, higher $\mathrm{Zn}$ concentration $\left(84.5 \mathrm{mg} \mathrm{kg}^{-1}\right.$ ) was found in location 8 and minimum $\mathrm{Zn}$ concentration of $36.0 \mathrm{mg} \mathrm{kg}^{-1}$ in location 4. In district Quetta, location 1 manifested $\mathrm{Zn}$ concentration of $77.9 \mathrm{mg} \mathrm{kg}-1$ in location 1 which is statistically higher $(\mathrm{p}<0.05)$ over other locations and lower $\mathrm{Zn}$ concentration (38.1 $\mathrm{mg} \mathrm{kg}^{-1}$ ) in location 3 whereas location 4, 5, and 8 expressed statistically at par differences in soil $\mathrm{Zn}$ level. Though, soil of apple orchards at district Ziarat revealed statistically $\quad(\mathrm{p}<0.05) \quad$ higher $\mathrm{Zn}$ concentration (101.6 mg kg $\mathrm{mg}^{-1}$ ) in location 5 and minimum of $37.7 \mathrm{mg} \mathrm{kg} \mathrm{Zn}$ concentration in location 4 respectively (Table 1). It demonstrates that the available $\mathrm{Zn}$ in soils of various locations of apple orchards across different districts of 
Balochistan fluctuates which might be due to differences in soil temperature, organic matter contents, soil texture, Soil supplied $\mathrm{Zn}$, moisture contents, $\mathrm{pH}$ and others. One factor is common in most soils of apple orchards that the soil $\mathrm{pH}$ falls in alkaline range where nutrient availability is the main constraints. But the majority of soil reflected AB-DTPA extractable $\mathrm{Zn}$ in marginal range instead of having high soil $\mathrm{pH}$ which could be due to applied Zinc sulfate in these sampled orchards and other Zinc improving factors. The effect of soil temperature on soil mineralization and decomposition of organic matter is reported by Davidson and Janssens [29] seems in line with the results of this study. The calcareous soil exists in arid and semi-arid area and have low organic matter and nitrogen. The calcareous soils are characterized by high $\mathrm{pH}$ and lime (calcium carbonate) that make phosphorus unavailable by forming calcium phosphate which is insoluble. The deficiencies of $\mathrm{Zn}$ and $\mathrm{Fe}$ in such soils are issues in agriculture production including apple and these deficiencies are also known as lime induced chlorosis [30].

Leaf tissue $\mathrm{Zn}$ status of apple orchards across five apple growing districts of Balochistan are given in (Table 2). One way analysis of variance of 30 orchards in three groups of ten orchards in each district revealed highly significant $(\mathrm{p}<0.05)$ differences in leaf $\mathrm{Zn}$ concentration. The results showed that in district Kalat the apple orchard's leaf $\mathrm{Zn}$ concentration (80.76 and $76.00 \mathrm{mg} \mathrm{kg}^{-1}$ ) was non-significantly higher in location 10 and 6 and minimum was noted location 5 which was statistically at par with location 8 and 9 . Whereas, in district Killa Abdullah higher leaf $\mathrm{Zn}$ concentration (104.07 $\mathrm{mg} \mathrm{kg} \mathrm{kg}^{-1}$ ) was recorded in location 9 immediately followed by $\mathrm{Zn}$ concentration of $97.37 \mathrm{mg} \mathrm{kg}^{-1}$ in location 5 and minimum $\left(19.50 \mathrm{mg} \mathrm{kg}^{-1}\right)$ in location 6 but the other locations expressed at par differences for $\mathrm{Zn}$ concentration. While, in district Pishin the non-significantly higher leaf $\mathrm{Zn}$ concentration (110.10 and $107.5 \mathrm{mg}$ $\mathrm{kg}^{-1}$ ) was observed in location 1 and 2 and minimum $\mathrm{Zn}$ concentration (14.33 $\mathrm{mg} \mathrm{kg}^{-1}$ ) was recorded in location 3 reflecting statistically at par differences for leaf $\mathrm{Zn}$ status in location 4-6. Similarly, apple orchards at district Quetta manifested higher leaf $\mathrm{Zn}$ concentration of $37.50 \mathrm{mg} \mathrm{kg}^{-1}$ in location 7 followed by $32.40 \mathrm{mg} \mathrm{kg}^{-1} \mathrm{Zn}$ in location 5 with lowest $\mathrm{Zn}$ status in location 8 . Likewise, apple orchards in location 2 and 3 at district Ziarat showed non-significantly higher leaf $\mathrm{Zn}$ concentration of 47.57 and $51.0 \mathrm{mg}$ $\mathrm{kg}^{-1}$ and minimum of $6.33 \mathrm{mg} \mathrm{kg}^{-1}$ in location 7. The variability in leaf $\mathrm{Zn}$ concentration of apple orchards across apple growing regions of Balochistan depicts spatial fluctuation which is due to change in summer temperature as district Killa Abdullah and plain area of Pishin district have comparatively higher temperature as compared to other three districts during summer but some locations like location 6 in both districts expressed lowest leaf $\mathrm{Zn}$ concentration which is due to mountainous and high elevation of the locations and are coolest area of these districts such as Toba Achakzai in Killa Abdullah and Toba Kakari in Pishin that have prominent symptoms of $\mathrm{Zn}$ deficiency. Similar narration has reported by Toselli et al. [31] and Weih and Karlsson [32] that plant growth is affected by soil temperature leading to influence root and shoot growth as well as nutrient uptake. The effect of temperature on nutrient uptake is due to changes in water viscosity and transport of nutrients [33, 34]. In surveillance study of fruit orchards for micronutrients conducted by Tariq et al. [35] in Peshawar valley reported deficiencies of micronutrients in various orchards reflecting iron by $45 \%, \mathrm{Cu} 13 \%, \mathrm{Mn}$ $2 \%$ and $\mathrm{Zn} 17 \%$. 
Table 1. Soil pH, EC $\mathrm{e}\left(\mathrm{dSm}^{-1}\right)$ and AB-DTPA extractable zinc concentration $\left(\mathrm{mg} \mathrm{kg}^{-1}\right)$ of apple orchards across 10 different locations of Kalat, Killah Abdullah, Pishin, Quetta and Ziarat districts, Balochistan (Pakistan)

\begin{tabular}{|c|c|c|c|c|c|c|c|c|c|c|c|c|c|c|c|}
\hline \multirow[b]{2}{*}{ Location } & \multicolumn{3}{|c|}{ Kalat } & \multicolumn{3}{|c|}{ Killah Abdullah } & \multicolumn{3}{|c|}{ Pishin } & \multicolumn{3}{|c|}{ Quetta } & \multicolumn{3}{|c|}{ Ziarat } \\
\hline & $\frac{\pi}{2}$ & 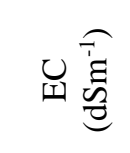 & 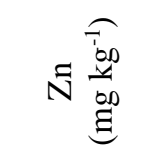 & $\frac{\pi}{2}$ & 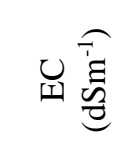 & 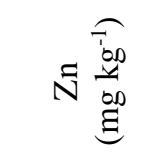 & 弯 & 茫 & 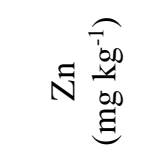 & $\frac{\pi}{2}$ & 诖 & 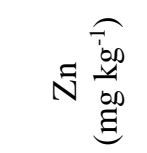 & $\frac{\pi}{2}$ & 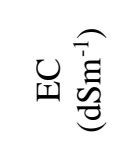 & 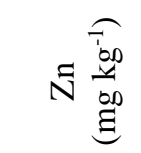 \\
\hline 1 & $8.18 \mathrm{a}$ & $3.45 \mathrm{ab}$ & $112.7 \mathrm{a}$ & $8.15 \mathrm{a}$ & $3.58 \mathrm{a}$ & $100.1 \mathrm{abc}$ & $8.18 \mathrm{~b}$ & $2.86 a$ & 62.7abcd & $8.13 \mathrm{ab}$ & $1.27 \mathrm{a}$ & $77.9 \mathrm{a}$ & $8.16 \mathrm{a}$ & $1.90 \mathrm{a}$ & $44.4 d$ \\
\hline 2 & $8.26 \mathrm{a}$ & $3.45 \mathrm{ab}$ & $96.9 \mathrm{ab}$ & $8.13 \mathrm{a}$ & $3.98 \mathrm{a}$ & $96.4 \mathrm{abc}$ & $8.27 \mathrm{ab}$ & $3.07 \mathrm{a}$ & $77.1 \mathrm{ab}$ & $8.23 \mathrm{ab}$ & $1.62 \mathrm{a}$ & $47.2 \mathrm{~cd}$ & $8.12 \mathrm{a}$ & $1.02 \mathrm{a}$ & $87.5 \mathrm{ab}$ \\
\hline 3 & $8.19 \mathrm{a}$ & $3.10 \mathrm{ab}$ & $104.7 \mathrm{a}$ & $8.17 \mathrm{a}$ & $3.99 \mathrm{a}$ & $102.1 \mathrm{ab}$ & $8.20 \mathrm{~b}$ & $2.56 \mathrm{a}$ & $58.7 \mathrm{bcde}$ & $8.12 b$ & $1.95 \mathrm{a}$ & $38.1 \mathrm{~d}$ & $8.07 a$ & $2.35 \mathrm{a}$ & $93.3 \mathrm{ab}$ \\
\hline 4 & $8.19 \mathrm{a}$ & $2.67 \mathrm{ab}$ & $88.5 \mathrm{abc}$ & $8.11 \mathrm{a}$ & $4.00 \mathrm{a}$ & $86.9 \mathrm{abcd}$ & $8.25 \mathrm{ab}$ & $3.10 \mathrm{a}$ & $36.0 \mathrm{e}$ & $8.33 \mathrm{ab}$ & $1.83 \mathrm{a}$ & $54.8 \mathrm{abcd}$ & $8.07 \mathrm{a}$ & $2.35 \mathrm{a}$ & $37.7 \mathrm{~d}$ \\
\hline 5 & $8.14 a$ & $2.85 \mathrm{ab}$ & $112.2 \mathrm{a}$ & $8.11 \mathrm{a}$ & $4.13 a$ & $110.5 \mathrm{a}$ & $8.20 \mathrm{~b}$ & $2.63 a$ & $40.2 \mathrm{de}$ & $8.32 \mathrm{ab}$ & $1.85 \mathrm{a}$ & $64.8 \mathrm{abc}$ & $8.11 \mathrm{a}$ & $1.05 \mathrm{a}$ & $101.6 \mathrm{a}$ \\
\hline 6 & $8.19 \mathrm{a}$ & $2.48 \mathrm{~b}$ & $58.5 \mathrm{~d}$ & $8.08 \mathrm{a}$ & $3.91 \mathrm{a}$ & $57.4 d$ & $8.35 \mathrm{a}$ & $3.53 \mathrm{a}$ & $48.8 \mathrm{cde}$ & $8.28 \mathrm{ab}$ & $2.23 a$ & $40.7 \mathrm{~cd}$ & $8.14 \mathrm{a}$ & $2.04 \mathrm{a}$ & $55.5 \mathrm{~cd}$ \\
\hline 7 & $8.18 \mathrm{a}$ & $2.81 \mathrm{ab}$ & $68.5 \mathrm{~cd}$ & $8.10 \mathrm{a}$ & $3.67 \mathrm{a}$ & $68.7 \mathrm{~cd}$ & $8.30 \mathrm{ab}$ & $2.32 \mathrm{a}$ & 62.1 abcd & $8.40 \mathrm{a}$ & $2.25 \mathrm{a}$ & 72.9ab & $8.26 a$ & $1.82 \mathrm{a}$ & $38.6 \mathrm{~d}$ \\
\hline 8 & $8.19 a$ & $2.80 \mathrm{ab}$ & $77.1 \mathrm{bcd}$ & $8.07 a$ & $3.93 \mathrm{a}$ & $77.8 \mathrm{bcd}$ & $8.24 \mathrm{ab}$ & $2.66 a$ & $84.5 \mathrm{a}$ & $8.35 \mathrm{ab}$ & $1.93 a$ & 58.3abcd & $7.83 a$ & $1.11 \mathrm{a}$ & $58.8 \mathrm{~cd}$ \\
\hline 9 & $8.26 \mathrm{a}$ & $3.07 \mathrm{ab}$ & 90.9abc & $8.12 \mathrm{a}$ & $3.72 \mathrm{a}$ & $90.3 \mathrm{abc}$ & $8.24 \mathrm{ab}$ & $2.33 \mathrm{a}$ & $70.4 \mathrm{abc}$ & $8.30 \mathrm{ab}$ & $1.69 \mathrm{a}$ & $41.2 \mathrm{~cd}$ & 7.99a & $1.27 \mathrm{a}$ & $48.6 \mathrm{~d}$ \\
\hline 10 & $8.26 \mathrm{a}$ & $3.94 \mathrm{a}$ & $71.3 \mathrm{bcd}$ & $8.09 a$ & $3.67 \mathrm{a}$ & $72.8 \mathrm{bcd}$ & $8.17 \mathrm{~b}$ & $2.77 \mathrm{a}$ & $65.9 \mathrm{abc}$ & $8.30 \mathrm{ab}$ & $1.81 \mathrm{a}$ & $49.5 \mathrm{bcd}$ & $8.08 \mathrm{a}$ & $1.94 \mathrm{a}$ & $74.9 \mathrm{bc}$ \\
\hline S.E. \pm & 0.07 & 0.69 & 12.80 & 0.078 & 0.639 & 15.18 & 0.066 & 0.621 & 11.23 & 0.136 & 0.746 & 11.67 & 0.288 & 0.812 & 11.16 \\
\hline LSD $(p<0.05)$ & 0.15 & 1.453 & 26.71 & 0.162 & 1.33 & 31.68 & 0.138 & 1.295 & 23.42 & 0.284 & 1.556 & 24.34 & 0.601 & 1.693 & 23.28 \\
\hline C.V. & 1.08 & 27.84 & 17.81 & 1.18 & 20.27 & 21.55 & 0.99 & 26.37 & 22.67 & 2.02 & 49.31 & 26.2 & 4.36 & 58.12 & 21.32 \\
\hline Mean square & $0.005^{\mathrm{NS}}$ & $0.576^{\mathrm{NS}}$ & $1069.5^{* *}$ & $0.003^{\mathrm{NS}}$ & $0.096^{\mathrm{NS}}$ & $847.5^{*}$ & 0.011 & $\begin{array}{c}0_{S} .413^{N} \\
\end{array}$ & $712.7^{* *}$ & $0.026^{\mathrm{NS}}$ & $0.209^{\mathrm{NS}}$ & $574.5^{*}$ & 0.039 & $\begin{array}{c}0.947^{\mathrm{N}} \\
\text { S }\end{array}$ & $1668.4^{* *}$ \\
\hline Minimum & 8.02 & 1.63 & 46.5 & 7.96 & 2.55 & 48.5 & 8.10 & 1.66 & 29.4 & 7.81 & 0.51 & 24.4 & 7.50 & 0.61 & 25.5 \\
\hline Maximum & 8.33 & 4.48 & 132.5 & 8.30 & 4.80 & 133.8 & 8.39 & 4.91 & 98.3 & 8.47 & 3.31 & 97.6 & 8.42 & 4.30 & 116 \\
\hline
\end{tabular}


Table 2. Zinc nutrient status of apple orchards in five districts of Balochistan

\begin{tabular}{|c|c|c|c|c|c|}
\hline \multirow{2}{*}{ Locations } & \multicolumn{5}{|c|}{ Apple growing districts } \\
\cline { 2 - 6 } & Kalat & $\begin{array}{c}\text { Killa } \\
\text { Abdullah }\end{array}$ & Pishin & Quetta & \multirow{2}{*|}{ Ziarat } \\
\hline 1 & $47.43 \mathrm{~cd}$ & $87.53 \mathrm{~cd}$ & $110.10 \mathrm{a}$ & $11.03 \mathrm{de}$ & $42.20 \mathrm{~b}$ \\
\hline 2 & $65.97 \mathrm{~b}$ & $92.60 \mathrm{bc}$ & $107.50 \mathrm{a}$ & $8.73 \mathrm{ef}$ & $47.57 \mathrm{a}$ \\
\hline 3 & $55.10 \mathrm{c}$ & $72.00 \mathrm{f}$ & $14.33 \mathrm{e}$ & $13.30 \mathrm{~d}$ & $51.00 \mathrm{a}$ \\
\hline 4 & $38.34 \mathrm{~d}$ & $89.83 \mathrm{bcd}$ & $17.73 \mathrm{e}$ & $17.04 \mathrm{c}$ & $12.27 \mathrm{ef}$ \\
\hline 5 & $18.53 \mathrm{e}$ & $97.37 \mathrm{ab}$ & $19.80 \mathrm{e}$ & $32.40 \mathrm{~b}$ & $8.47 \mathrm{fg}$ \\
\hline 6 & $76.00 \mathrm{a}$ & $19.50 \mathrm{~g}$ & $16.70 \mathrm{e}$ & $16.60 \mathrm{c}$ & $9.70 \mathrm{fg}$ \\
\hline 7 & $44.26 \mathrm{~d}$ & $77.17 \mathrm{ef}$ & $44.50 \mathrm{~d}$ & $37.50 \mathrm{a}$ & $6.33 \mathrm{~g}$ \\
\hline 8 & $19.33 \mathrm{e}$ & $90.10 \mathrm{bcd}$ & $61.13 \mathrm{c}$ & $7.13 \mathrm{f}$ & $15.70 \mathrm{de}$ \\
\hline 9 & $16.60 \mathrm{e}$ & $104.07 \mathrm{a}$ & $87.97 \mathrm{~b}$ & $10.23 \mathrm{def}$ & $18.10 \mathrm{~d}$ \\
\hline 10 & $80.76 \mathrm{a}$ & $84.43 \mathrm{de}$ & $51.27 \mathrm{~d}$ & $18.70 \mathrm{c}$ & $37.57 \mathrm{de}$ \\
\hline S.E.土 & $\mathbf{4 . 6 5}$ & $\mathbf{3 . 6 2}$ & $\mathbf{4 . 3 2}$ & $\mathbf{1 . 5 3}$ & $\mathbf{1 . 8 8}$ \\
\hline LSD (p<0.05) & $\mathbf{9 . 7 0 0}$ & $\mathbf{7 . 5 5}$ & $\mathbf{9 . 0 1}$ & $\mathbf{3 . 1 9}$ & $\mathbf{3 . 9 3}$ \\
\hline C.V. & $\mathbf{1 2 . 3 2}$ & $\mathbf{5 . 4 4}$ & $\mathbf{9 . 9 6}$ & $\mathbf{1 0 . 8 4}$ & $\mathbf{9 . 2 7}$ \\
\hline Mean square & $\mathbf{1 6 6 1 . 6 1 * *}$ & $\mathbf{1 6 7 5 . 4 6}$ & $\mathbf{4 2 5 1 . 1 4 * *}$ & $\mathbf{3 0 6 . 8 4}$ & $\mathbf{9 3 0 . 3 4}$ \\
\hline Minimum & $\mathbf{1 4 . 6}$ & $\mathbf{1 7 . 6}$ & $\mathbf{1 1 . 7}$ & $\mathbf{5 . 6}$ & $\mathbf{5}$ \\
\hline Maximum & $\mathbf{8 5 . 1}$ & $\mathbf{1 1 2 . 2}$ & $\mathbf{1 2 0 . 1}$ & $\mathbf{3 9 . 3}$ & $\mathbf{5 5 . 2}$ \\
\hline
\end{tabular}

Number of apple orchards showing leaf tissue $\mathrm{Zn}$ status are illustrated in (Figure 1). Leaf tissue $\mathrm{Zn}$ concentration of $15-19 \mathrm{mg}$ $\mathrm{kg}^{-1}$ is validated low, $20-100 \mathrm{mg} \mathrm{kg}^{-1}$ is medium while $>100 \mathrm{mg} \mathrm{kg}^{-1}$ is high. In light of these interpretation guidelines, the distribution of 30 apple orchards in each district revealed $\mathrm{Zn}$ status in varying degree. It was observed that out of 30 apple orchards in district Kalat 7 orchards were found low in leaf tissue $\mathrm{Zn}$ status and 23 orchards were found in medium range but none of the orchard indicated higher leaf $\mathrm{Zn}$ concentration. In Killa Abdullah district, two orchards showed lower leaf $\mathrm{Zn}$ and two high but 23 orchards manifested leaf $\mathrm{Zn}$ status in medium range. Likewise, in district Pishin 10 orchards indicated lower leaf $\mathrm{Zn}$ concentration, 15 in medium range and 5 in higher range. In case of Quetta district, out of 30 orchards, 22 orchards revealed leaf $\mathrm{Zn}$ concentration in low range and 8 in medium range but none of orchard was found in higher leaf $\mathrm{Zn}$ status. Whereas, in district Ziarat, 17 apple orchards expressed leaf $\mathrm{Zn}$ concentration in low range and 13 were in medium range.

Number of apple orchards indicating ABDTPA extractable soil $\mathrm{Zn}$ status are represented in (Figure 2). The interpretation of the AB-DTPA extractable soil $\mathrm{Zn}$ designate that $\mathrm{Zn}$ concentration $<60 \mathrm{mg} \mathrm{kg}{ }^{-1}$ is considered low, 60-120 mg kg-1 is marginal while $>120 \mathrm{mg} \mathrm{kg}^{-1}$ is adequate. Soil $\mathrm{Zn}$ in apple orchards in district Kalat was low in 5 orchards, high in 2 and marginal in 23 orchards while in Killa Abdullah, low in 3, marginal in 24 and high in 3 orchards. Similarly, in district Pishin 15 orchards showed low soil $\mathrm{Zn}$ and 15 in marginal range while 20 orchards in Quetta expressed low soil $\mathrm{Zn}$ and 10 orchards were found in marginal range. However, none of the orchards in Pishin, Quetta and Ziarat showed adequate soil $\mathrm{Zn}$. The variability in the available soil $\mathrm{Zn}$ was due to differences in soil physicochemical characteristics and same reasons was reported by Zia et al. [36] that soils vary substantially in $\mathrm{pH}, \mathrm{EC}$, moisture content, organic matter and types of minerals in the soil that drive the 
availability of nutrients. Further, when soil temperature increases it indirectly enhance root growth performance [37] but decrease in soil temperature slow down the growth performance of roots and indirectly lowers nutrients concentration in plant tissue [38, 39].

The percentile $\mathrm{Zn}$ status of 150 apple orchards in five districts of Balochistan is presented in (Figure 3) as percent of 30 orchards in each district. The overall picture of $\mathrm{Zn}$ status of apple orchards showed that $23.3 \%$ apple orchards were found $\mathrm{Zn}$ deficient in Kalat, $6.7 \%$ in Killa Abdullah, $33.3 \%$ in Pishin, $73.3 \%$ in Quetta and $56.7 \%$ in district Ziarat. The $\mathrm{Zn}$ deficiencies in these apple orchards need to be removed by applying Zinc sulphate through soil or spray in the dormant period i.e. before buds breaking. If $\mathrm{Zn}$ deficiencies were not corrected timely, then these orchards will be succumbed to fungal attack and die back.

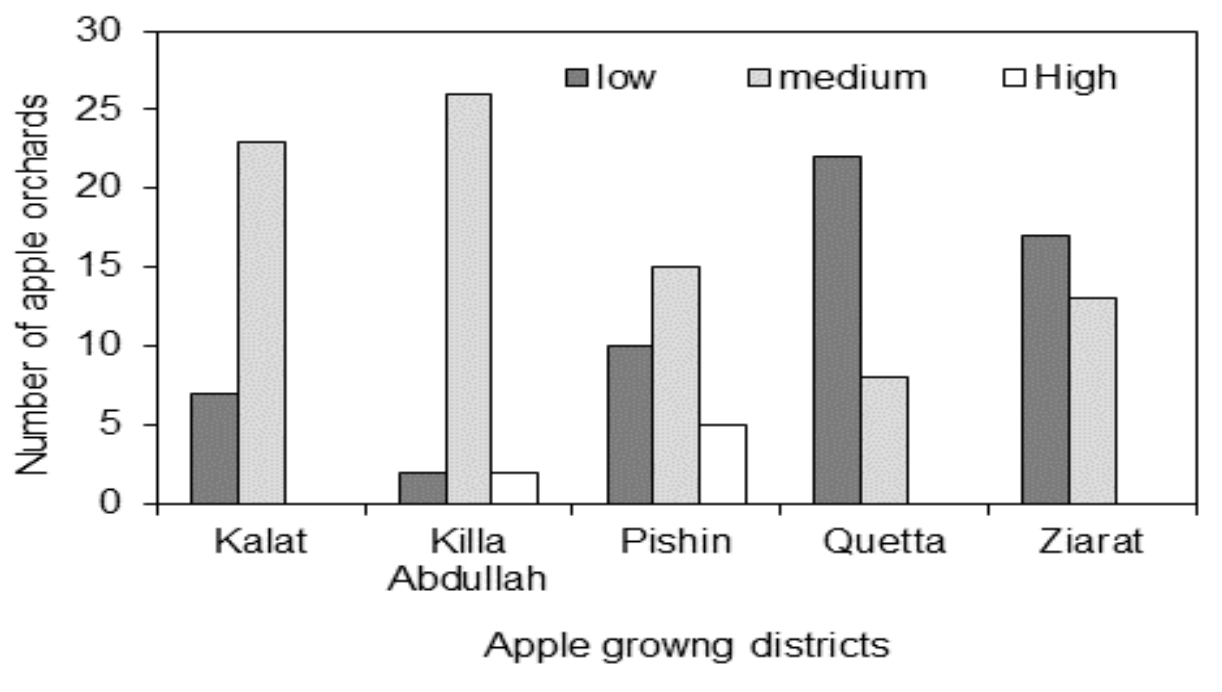

Figure 1. Number of apple orchards indicating leaf tissue Zinc status across five districts of Balochistan

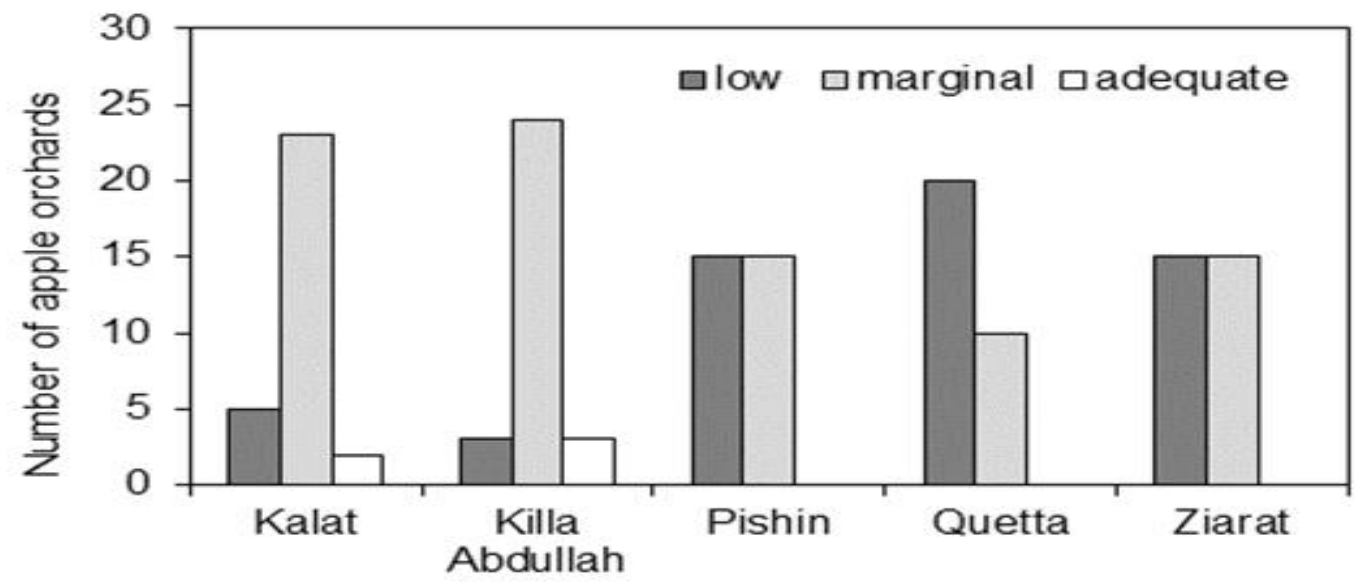

Apple growng districts

Figure 2. Number of apple orchards indicating AB-DTPA extractable soil Zinc status across five districts of Balochistan 


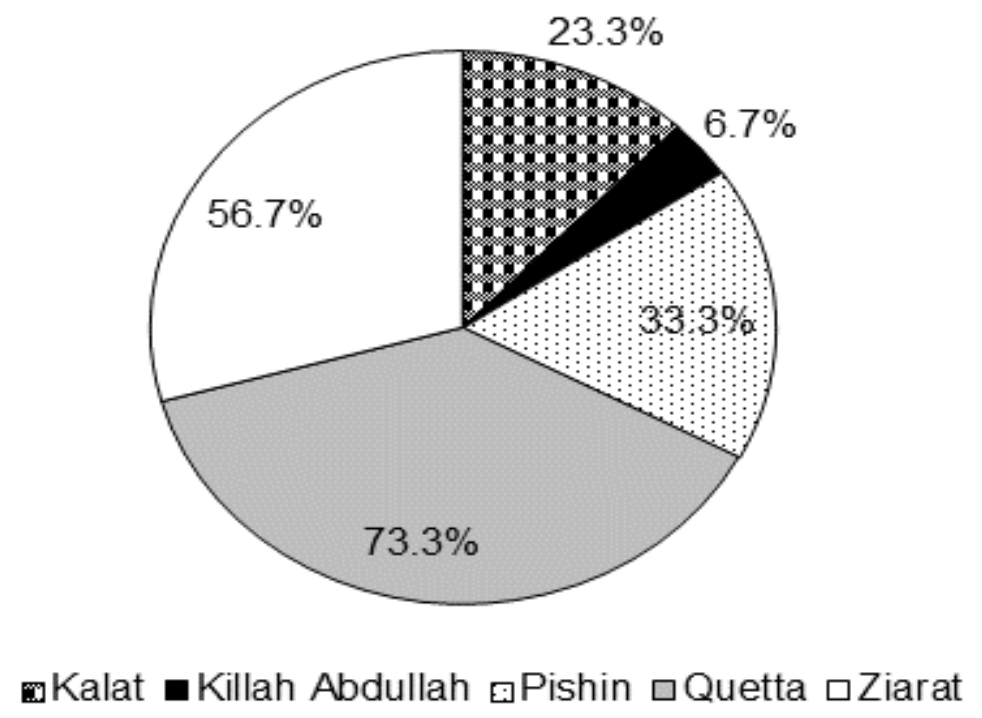

Figure 3. Percent leaf Zinc deficiency in apple orchards of five districts of Balochistan

\section{Conclusion}

In the light of soil testing and leaf tissue analysis data, it is inferred that most apple orchards of district Kalat, Killa Abdullah, Pishin, Quetta and Ziarat were found deficient in soil and leaf tissue $\mathrm{Zn}$ concentration. While, soil of these orchards is alkaline in nature and so make micronutrients particularly Zn unavailable to plants. Consequently, this study suggest that Zinc supplementation to soil of these orchards are needed while the addition of compost under such alkaline soil also necessary which is considered as one of the best management practices for apple orchards.

\section{Authors' contributions}

Conceived and designed the experiments: Hidayatullah, Performed the experiments: Z Khan, Analyzed the data: SAH Agha, Contributed materials/ analysis/ tools: Hidayatullah, R Kethran, Wrote the paper: Hidayatullah, NA Alizai.

\section{References}

1. Nielsen FH (2012). History of Zinc in Agriculture. Adv Nutr 3(6): 783-789.
2. Broadley MR, Philip JW, John PH, Ivan Z \& Alexander L (2007). Zinc in plants. New Phytol 173: 677-702.

3. Marschner H (1995). Mineral Nutrition of Higher Plants, $2^{\text {nd }}$ Ed. Academic Press; London.

4. Alloway BJ (2009). Soil factors associated with zinc deficiency in crops and humans. Environ Geochem Health 31(5): 537-48.

5. Rashid A, Rafique E, Bughio N \& Yasin M (1997). Micronutrient deficiencies in rainfed calcareous soils of Pakistan. IV. Zinc nutrition of sorghum. Commun Soil Sci Plant Anal 28(6-8): 455-67.

6. Sillanpaa M (1990). Micronutrient assessment at the country level: An international study, FAO Soils Bulletin 63. FAO/ Finish International Development Agency, Rome, Itlay.

7. Wojcik P (2007). Vegetative and reproductive responses of apple trees to zinc fertilization under conditions of acid coarse textured Soil. J Plant Nutr 30: 1791-1802. 
8. GOP (2008). Agricultural Statistics of Pakistan. Ministry of Food and Agriculture Economic Wing, Govt. of Pakistan, Islamabad.

9. Lindsay WL (1972). Inorganic phase equilibria of micronutrients in soils. $\mathrm{p}$. 41-57. In: Micronutrients in Agriculture. JJ Mortvedt, PM Giordano and WL Lindsay (eds.). Soil Science Society of America, Inc. Madison, Wisconsin USA.

10. Chapman HD (1966). Zinc. p. 484-499. In: Diagnostic Criteria for Plants and Soils. H.D. Chapman (ed.). University of California, Division of Agricultural Science, Riverside, California.

11. Rashid A \& Ryan J (2004). Micronutrient constraints to crop production in soils with Mediterraneantype characteristics: A review. J Plant Nutr 27: 959-975.

12. Lebourge A, Sterckeman T, Ciesielski H \& Proix N (1998). Trace metal speculation in three unbuffered salt solutions used to assess their bioavailability in soil. J Environ Qual 27: 584-590.

13. Alloway BJ (2008). Zinc in Soils and Crop Nutrition. $2^{\text {nd }}$ Ed. IZA and IFA, Brussels, Belgium and Paris, France.

14. Cakmak I (2008). Enrichment of cereal grains with zinc: agronomic or genetic biofortification. Plant Soil 302: 1-17.

15. Fageria NK (2002). Influence of micronutrients on dry matter yield and interaction with other nutrients in annual crops. Pesq Agropec Bras 37: 1765-1772.

16. Fageria NK (2004). Dry matter yield and nutrient uptake by lowland rice at different growth stages. $J$ Plant Nutr 27(6): 947-958.

17. Malle KG (1992). Zinc in Environment. Acta Hydrochim Hydrobiol 20:196-204.

18. Barber SA (1995). Soil Nutrient Bioavailability: A Mechanistic
Approach $2^{\text {nd }}$ Ed. John Wiley \& Sons, Inc, New York.

19. Kiekens L (1995). Zinc. In: Alloway, B.J., Ed., Heavy Metals in Soils. $2^{\text {nd }}$ Ed. Blackie Academic and Professional, London 284-305.

20. Kabata-Pendias A \& Pendias H (1999). Biogeochemistry of Trace Elements. $2^{\text {nd }}$ Ed. Wyd Nauk PWN, Warszawa (in Polish).

21. Kabata-Pendias A \& Pendias H (2001). Trace Elements in Soils and Plants. $3^{\text {rd }}$ Ed. CRC Press, Inc, Boca Raton, Florida (USA).

22. Dris R \& Niskanen R (2004). Leaf and fruit macronutrient composition during the growth period of apples. J Food Agric Environ 2(3-4): 174-176.

23. Sonneveled C \& Van Dijk PA (1982). The effectiveness of some washing procedures on the removal of contaminates from plant tissues of glasshouse crops. Commun Soil Sci Plant Anal 13: 487-496.

24. Ryan J, Estefan G \& Rashid A (2001). Soil and Plant Laboratory Manual. $2^{\text {nd }}$ Ed. ICARDA Aleppo, Syria and NARC, Islamabad.

25. McKeague JA (Ed.) (1978). Manual on soil sampling and methods of analysis. Can J Soil Sci 66-68.

26. McLean EO (1982). Soil $\mathrm{pH}$ and lime requirement P. 199-224. In: Page, A.L. (Ed.), Methods of soil analysis, Part 2: chemical and microbiological properties. Am Soc Agron, Madison, WI (USA).

27. Sultan pour PN \& Schwab AP (Eds.) (1977). A new soil test for simultaneous extraction of macro-micro nutrients in alkaline soils. Commun Soil Sci Plant Anal 8: 195-207.

28. Wolf B (1982). A comprehensive system of leaf analysis and its use for diagnosing crop nutrient status. 
Commun Soil Sci Plant Anal 13:10351059.

29. Davidson EA \& Janssens IA (2006). Temperature sensitivity of soil carbon decomposition and feedbacks to climate change. Nature 440: 165-173.

30. Uygur V \& Rimmer DL (2000) Reactions of zinc with iron coated calcite surfaces at alkaline pH. Eur $J$ Soil Sci 51: 511-516.

31. Toselli M, Flore JA, Marogoni B \& Masia A (1999). Effects of root-zone temperature on nitrogen accumulation by non-breeding apple trees. $J$ hort $S c i$ Biotech 74: 118-124.

32. Weih M \& Karlson S (1999). The nitrogen economy of mountain birch seedlings: implication for winter survival. J Ecol 87(2): 211-219.

33. Grossnickle SC (2000). Ecophysiology of Northern spruce species in the performance of planted seedlings. NRCCNRC, NRC, Research press, Ottawa Ont, Canada, pp 325-407.

34. Lahti M, Aphalo PJ, Finer L, Lehto T, Leinonen I \& et al. (2002). Soil temperature, gas exchange and nitrogen status of 5-year old Norway spruce seedlings. Tree physiol 22(18): 13111316.

35. Tariq M, Shah Z \& Ali A (2008). Micronutrients status of plum orchards in Peshawar valley. Soil Environ. 27(2): 223-227.

36. Zia MJ, Ahmad R, Khaliq I, Ahmad A \& Irshad M (2014). Micronutrient status and management in citrus orchard soil: Applied aspect. Soil Environ 25(1): 616.

37. Repo TI, Leinonen AR \& Finer L (2004). The effect of soil temperature on bid phenology, chlorophyll fluorescence, carbohydrate content and cold bardiness of Norway spruce seedlings. Physio Plant 121: 93-100.

38. Balland V \& Arp PA (2005). Modeling soil thermal conductivities over a wide range of conditions. J Environ Eng Sci 4(6): 549-558.

39. Puhe J (2003). Growth and development of the root system of Norway spruce (Picea abies) in forest stands-a review. Ecol Manag 175(1-3): 253-273. 